\title{
Farming systems and crop-livestock land use consensus. Tanzanian perspectives
}

\author{
Dunstan Gabriel Msuya \\ Department of Crop Science and Production, Sokoine University of Agriculture, Morogoro, Tanzania; dmsuya@suanet.ac.tz
}

Received 28 September 2013; revised 1 November 2013; accepted 8 November 2013

Copyright (C) 2013 Dunstan Gabriel Msuya. This is an open access article distributed under the Creative Commons Attribution License, which permits unrestricted use, distribution, and reproduction in any medium, provided the original work is properly cited.

\begin{abstract}
Agriculture is an important source of economic survival of rural populations, and with great power for poverty reduction in the economy. For this reason farming systems that are most efficient have to be sought. This paper explores crop-based and pastoralism farming systems under conflicting land use relations. Incidences of violent conflicts are highlighted, which usually assume a depoliticised expression as inter-group conflicts. Competition for resources (land and water) is an important reason for such conflict, but the role of the state in protection of property rights is also advocated to nurture rivalry. Very wide difference in conception, that to the pastoralists property is cattle, land is common property open to herds, while to crop farmers land is property, which is divided between households, complicates the conflict resolution. State bias exists in the protection of property rights. Mechanisms for the state bias are briefly cited. This paper suggests a farming systems educational approach as a way to reduce environmentally stressful practice, and strengthen the study of administrative regulation that harmonizes equity in conflicting land use.
\end{abstract}

Keywords: Farming Systems; Pastoralism; Land Use Choices; Farmer-Herder Conflicts

\section{INTRODUCTION}

Cultivation of crops and rearing of domesticated animals, or in other words "Agriculture", is the backbone of economies and survival in most of the developing countries. Globally agriculture provides livelihoods and jobs for about $40 \%$ of the population in the meantime [1]. In Sub-Saharan Africa, according to OECD [2], agriculture accounts for $20 \%$ of the Gross Domestic Product and employs about $67 \%$ of the total labour force, on the average. Tanzanian agriculture, on the other hand, is the economic activity for the survival of about more than $80 \%$ of the country population $[3,4]$.

Much of developing countries' economic growth is still dependent on agriculture, the power of which comes from, according to de Janvry and Sadoulet [5], its potentially strong growth linkage effects on the rest of the economy, and from its direct poverty reduction effect. Export agriculture in Tanzania, for example, is reported [6] to generate $80 \%$ spin-off benefits in terms of demand for consumption of goods and services in the surrounding economy, hence employment or income generation opportunities, comparative to only $20 \%$ for urban light manufacturing.

Therefore one of the most important necessities for pursuing urgent agricultural development is its power in poverty reduction. Generally, it has been established that economic growth originating from agriculture is at least three times as effective in reducing poverty as growth originating from the rest of the economy [5]. It is for this reason that farming systems that are most efficient have to be sought. This choice can only be made when we are fully aware of gaps in our system that hamper development. One problem that much of the less developed world must continually strive to end is a system-based long time state of conflict and often violence between two groups of the rural land users: farmers and pastoralists, who would in the contrary be prospering agricultural stakeholders because of secured land use choices.

\section{AGRICULTURE AND FARMING SYSTEMS}

Actual practice of agriculture is exercised through farming systems. There are many definitions for the word "farming systems". Perhaps best ones are: "Decision making and land use units consisting of farm households, cropping and livestock systems that produce 
crop and animal products for consumption and sale [7]"; "Units consisting of human groups (usually households) and resources they manage in their environments, involving the direct production of plant and/or animal products [8]"; "Combinations of products and production factors applied by the farm households including all subsystems of land utilization (crops, forests, herds, hunting, gathering etc. [9]"; "Complex of development, management and allocation of resources as well as decisions and activities that within an operational farm unit or a combination of such units results in agricultural production, and the processing, marketing (and utilizetion) of the products [10]"; "Populations of individual farm systems that have broadly similar resource bases, enterprise patterns, household livelihoods and constraints, and for which similar development strategies and interventions would be appropriate [11].

Thus a farming system is in-depth description of agricultural practice, including all specifics of scenarios determining patterns of the practice. The way crops are cultivated or animals are reared, the organization of labour and relationships, resources available including land, species of crops and crop varieties; species of animals and animal breeds, intensities of resource use, motives persuading production, market links, utilization and value addition patterns, relationships with external environments of capital and expenditure, norms and customs, traditions, weather and climate, soils and watershed characteristics, terrain and topography, policies, programmes and projects; the law, institutions of service and change; indigenous and formalized education systems; and what not, all these sum up into the existing farming system. None among them is perhaps less important. Farming systems are therefore real complexes. Any efforts to improve one element can lead to tremendous improvement of other elements. Agriculture we see is therefore an image or reflection of the interplay of the various elements. Patterning is a constant trend towards more equilibrium state. Whether by choice or spontaneity, patterning is there and the fate or destiny of agriculture is responsive of the patterning trends existing. It is our obligation to choose towards the most balanced equilibrium, which then stabilizes the system. Short of this we become driven by spontaneity, and our agriculture becomes not what we want, agriculture of crises, agriculture of shortfalls, backwardness, often poverty-stricken.

\section{FARMING SYSTEMS AND LAND USE}

Farming systems are in other words land use patterns. They are representations of the relation of man to land. Through farming systems the farmer is able to transform land into livelihood. The system tells about efficiency and success. More precisely, of course, farming systems are agricultural land use patterns, considering other land uses like settlement, mining and other economic and infrastructural activities. Farming systems underscore at least the two most natural land uses, farming and the households or in other words farmers' settlement. Generally, study of land use categorizes land use into two broad types: rural (agricultural, forestry, game cropping) land use and urban (including industrial) land use. Agricultural land use then paves way for development of farming systems.

There are many different descriptions of the typology of farming systems. One of best known such classifications is one by Ruthernberg [12] who describes tropical farming systems to belong to either of the following types: shifting cultivation systems, fallow systems, ley and dairy systems, systems with permanent upland cultivation, systems with arable irrigation farming, systems with perennial crops, and grazing systems, including ranching. With agriculture embracing generally cultivation of crops or rearing of domesticated animals, farming systems can therefore also be categorized as crop-based farming systems and animal-based systems. Consequently livelihood is attached to either of the two categories. Arable crop based (cereals, grain legumes, oilseeds, roots and tubers, all staple food and to some extent industrial cash crops, usually of annual, at most semi-perennial cropping cycles) farming systems are the predominant farming systems in most of the agricultural world. This is the group that generally feeds the hungriest world. Then there are systems based on the rest of the crops, such as horticultural and plantation crops; and also several animal-based farming systems. Farming systems generally vary in intensity and degree of complexity. Thus shifting cultivation systems (involving clearing land with such practices as slash and burn, cultivating for a short period of time and then abandoning the land to clear another area) are more primitive than systems with arable irrigation farming, systems with perennial crops, etc. Likewise grazing systems are less complex in terms of resource use than, for example, ley and dairy systems.

Even though crop based systems are predominant, animal or livestock based farming systems are also a very important category of agricultural land use. Animal based systems can generally be described as pastoral farming systems based on natural pastures, and intensive livestock farming systems such as dairy systems, poultry, piggery and aquaculture, and including mixed farming. Pastoral or in other words grazing farming systems vary in their settlement characteristics. They include pastoralism, agro-pastoralism and the more modern form: ranching. Pastoralism has been defined as a production system in which livestock owners depend solely on livestock and livestock products for sustenance and income, en- 
tailing seasonal movement in search of water and pasture [13]. Various forms of pastoralism are extensively explained in literature, they include nomadic pastoralism or nomadism, which involves no settlement but all-time movement with grazing livestock; semi-nomadic pastoralism; semi-settled pastoralism and settled pastoralism. When pastoralists depend on both livestock and crop farming for their sustenance and income generation, the system is known as agro-pastoralism [13]. Two types of agro-pastoralism are generally known: Transhumance where the pastoralists cultivate crops at one area and move all or most of their livestock to other grazing areas during non-grazing season; and Sedentary agro-pastoralism where the pastoralists keep livestock throughout the year near their cropping activities. Ranching is a modernized and commercial form of grazing or pastoral system in which, according to Pratt et al. [14], animals are exploited on a demarcated area of rangeland that is privately owned or allocated for that purpose; usually involving large tracts of land [15] and large herds of grazing animals [16].

\section{CROP-LIVESTOCK LAND USE CONCENSUS}

Evolution of farming systems has not been without constraint of land use choices. The rule seems to have been intensification. Earliest man lived by hunting animals that were then living in the wild, and gathering crop food products - fruits, roots and tubers, grains and herbs, all from the wild also. Then he discovered agriculture, and domesticated the multitudes of crop plants and animals now used as food and other products. Domestication enabled settled livelihood, and through variation in intensity of crop cultivation and rearing of animals now we have modern agriculture, and urbanization. These are changes in land use pattern. The changes are both ecological and economic adjustments responsive to human population changes both in rural and urban areas. In time vast wilderness diminishes and land use becomes more and more competitive. An equilibrium must then be reached through more organized land use.

There are times of rivalry in land use, before land use plan is settled or an equilibrium is reached. In Africa conflict between farmers and pastoralists, according to Moritz [17], can be traced back as far as four centuries ago (1600 AD) when "white warriors", herders from the northern Sahel, continuously raided the black agricultural villages in south (for the sake of grazing land). In the Middle East [18] there was an endless struggle between the nomadic Bedouin and the fellahin (peasants) in the Arab societies. Even in the western countries clashes have happened over grazing land, for example the Johnson County Range War of 1892 in the Great Plains of Wyoming, USA, between cattlemen and homesteaders (sedentary farmers) [19]. In post-colonial Africa to-date innumerable violent conflicts have been happening between the two, essentially opposing land users, the farmers and pastoralists. In Bukina Faso, for example, IRIN [20] reports that about 600 conflicts occur each year between farmers and herders, involving human casualties, destruction of farms and death of animals; and that between 2007 and 2012 as many as 55 people were killed in 4000 recorded clashes between the two groups. Bloody rivalries have been reported quite in recent times in many other countries including Nigeria [21,22], Mali [23], Ethiopia [24,25], Kenya [26], etc. These incidences are more elaborated in Table $\mathbf{1 .}$

Table 1. Some incidences of land use conflict between farmers and pastoralists in selected sub-Saharan African countries.

\begin{tabular}{|c|c|c|c|}
\hline Country & Years & Incidence & Consequences \\
\hline \multirow{2}{*}{ Nigeria } & 2005 to 2010 & $\begin{array}{l}\text { Clashes between farmers } \\
\text { and pastoralists }\end{array}$ & $\begin{array}{l}280 \text { people dead, } 7000 \text { hectares of farms destroyed, } \\
1300 \text { cattle lost, } 7 \text { communities sacked }\end{array}$ \\
\hline & 2009 & $\begin{array}{l}\text { Clashes between farmers } \\
\text { and pastoralists }\end{array}$ & 32 people dead, houses and farms destroyed \\
\hline Mali & 2012 & $\begin{array}{l}\text { Dogan farmers clash } \\
\text { with Fulani herders }\end{array}$ & $\geq 25$ people dead \\
\hline \multirow{2}{*}{ Bukina Faso } & Every year & 600 farmer-herder conflicts & $\begin{array}{l}\text { Death of humans, injury or death of animals, } \\
\text { destruction of houses }\end{array}$ \\
\hline & 2007 to 2012 & 4000 recorded clashes & 55 people dead \\
\hline Bukina Faso (Balere, East Region) & 2003 & Farmer-herder conflict & 10 herders killed for destroying farmers' crops \\
\hline Ethiopia $^{\mathrm{a}}$ & 1994 to 2002 & Farmer-pastoralist violent conflicts & 116 people dead, 616 animals killed and lost \\
\hline Kenya (Tana river) & 2012 & Farmers and pastoralists clashes & $\geq 48$ people dead, 60 cattle killed \\
\hline
\end{tabular}

${ }^{\mathrm{a}}[24] ;{ }^{\mathrm{b}}[25]$. 


\subsection{Tanzanian Perspectives}

Tanzania, too, in areas where crop farmers and traditional animal keepers, the pastoralists, interact, rivalry has always been there. Tanzanians have enjoyed customary land rights for a very long time, but the state has also strived to achieve control. Despite all regulatory effort, however, ranging from the National land policy of 1995; the Agriculture and Livestock Policy of 1997 [3]; the Village Land Act No. 5 of 1999; The Land Disputes Act No. 2 of 2002; the National Livestock Policy of 2006; the National Land Use Plan Act of 2007 and the Grazing Land and Animal Feed Act No. 13 of 2010, the problem is still there and perhaps not less than before. It is obvious that there is still a lot to be accomplished or consolidated.

Tanzanian territory is made up of about 88.6 million hectares of land [27] out of which about 44 million hectares are claimed to be utilized by the livestock sub-sector [28]. Another 44 million hectares is claimed to be available for cultivation [29]. The nation's resources of permanent pastures have been estimated to be about 35.5 million hectares [30]. With 44 million hectares for livestock against 35.5 million permanent pastures, the statistics show that there is overgrazing of pasturelands taking place in about 8.5 million hectares outside the permanent pasture area [28]. This is an important question at the level of agricultural land policy. The statistics further show average land use in Tanzania to be about 2.2 hectares per cow [28] while for crop farming lands it averages only about 1.2 hectares $(\approx 3$ acres $)$ per farmer, according to ALP [30]. Talking about food security and reduction of poverty the average cropland per farmer is inadequate. Lugoe [28] concludes that "careful examina- tion of various land statistics in Tanzania point a possibility of land scarcity and not abundance as portrayed on policies on agriculture".

So there are statutory efforts and statistics which point to the role government planning has to solve the land use rivalry. Behind these there is an always much more urgent scenario which demonstrate the problem in greater in-depth perspectives. This is the question of physical encounters between the rival groups, causing losses of lives and property within such time intervals when the state regulation power cannot be of use if gaps exist. This has happened and is widespread allover the country (Tanzania) from north east to southwest, central to east, as shown in Table 2.

The problem of land use consensus between pastoralists and farmers can only be resolved through explicit policy, administrative regulation and farming systems education. In Tanzania, the necessary land use planning machinery has been established through the National Land Use Plan Act (No. 10) of 2007; but there seems to be gaps not yet filled to resolve pastoralist - farmer tension in endemic areas. While the next legislation relevant to land use, the Grazing Land and Animal Feeds Act (No. 13) of 2010 provides for the Grazing Land Development and Management (Part III of the Legislation), it does not state anything specific on crop fields used for grazing even though the legislation generally recognizes existence of agro-pastoralism. The Land Disputes (Courts for Land Disputes Settlement) Act (No. 2) of 2002 focuses on mechanisms of dispute settlement but not at all any definition of specific disputes, therefore cannot allow sufficient specific resolution of crop-livestock interaction tension.

Table 2. Selected record of clashes over land use rights between crop farmers and pastoralists in Tanzania.

\begin{tabular}{|c|c|c|c|}
\hline Area & District & Year & Consequence \\
\hline Ihefu, Usangu & Mbarali & 2007 to 2009 & Removal of about 1000 pastoral families \\
\hline Mabwegere and Ngaiti Villages & Kilosa & 2000 to 2009 & \\
\hline Rudewa-Mbuyuni Village & Kilosa & 2000 & 38 farmers killed \\
\hline Kikenge Hamlet, Mabwegere & Kilosa & 2008 & $\begin{array}{l}8 \text { people killed, crops destroyed, houses burnt, } \\
\text { thousands of livestock stolen }\end{array}$ \\
\hline Ikwiriri $^{a}$ & Rufiji & 2012 & One farmer killed, violent riots \\
\hline Mvomero, Mikumi, Kilombero & Mvomero Mikumi Kilombero & 2000 to 2009 & \\
\hline Mpanda, Nkasi, Sumbawanga & Mpanda Nkasi Sumbawanga & 2009 & \\
\hline Kilindi, Kiteto & Kilindi Kiteto & 2008 to 2009 & Several human casualties, houses destroyed ${ }^{\mathrm{e}}$ \\
\hline $\begin{array}{l}\text { Loliondo (Sonjo farmers } \\
\text { and Maasai pastoralists) }\end{array}$ & Ngorongoro & 2000 to 2009 & $\begin{array}{l}\text { Several human casualties, injuries, houses burnt, } \\
\text { livestocklost }{ }^{(\mathrm{b}, \mathrm{c}, \mathrm{d})} \text {, about } 5000 \text { humans dead since } 1880^{\mathrm{d}}\end{array}$ \\
\hline Dumila & Mvomero & 2013 & $\begin{array}{l}\text { Death, injury, houses and property destruction, } \\
\text { violent riots }^{\mathrm{f}}\end{array}$ \\
\hline
\end{tabular}

Source: $[28] .{ }^{\mathrm{a}}[31],{ }^{\mathrm{b}}[32],{ }^{\mathrm{c}}[33],{ }^{\mathrm{d}}[34],{ }^{\mathrm{e}}[35],{ }^{\mathrm{f}}[36]$. 
No wonder that current legislation in Tanzania may not be sufficient in ensuring justice to crop farmers and animal herdsmen overlapping interests, Lugoe [28] argues that there is an important misallignment between the Livestock policy (of 2006) and the National Land Policy. While the livestock policy recognizes seasonal movement as an important characteristic of pastoralism, the NLP prohibits nomadism. Ibid points out a suggestion that the land policy position on prohibiting nomadism should apply to all its different forms - modern or transhumant or what else. This is not easy to achieve, since the livestock policy in the contrary protects pastoralism and provides clauses for agro-pastoralism and livestock agriculture reflecting that pastoralism and livestock agriculture are congruent practices. These gaps in policy thus expose a question of "what is Government's firm position on pastoralism and where in policy this is reflected"? (Ibid)

There therefore seems to be further steps necessarily to be taken to totally settle the farmer-herder conflict in Tanzania. The Livestock Sector Development Programme [37], designed to implement the NLP of 2006, expresses its satisfaction that by its inception about 1.4 million hectares of land for grazing livestock had already been demarcated in 266 villages of 15 regions in mainland Tanzania. This is surely the right trend if herders can really settle in pastoralist villages. When all potentially grazing land has been demarcated there may be lasting peace between pastoralists and farmers. Two extra efforts seem paramount. One is strengthening of administrative machinery to make sure that livestock may no longer be stray into crop lands. Perhaps at this juncture new legislation may be necessary. There seems to be need for an extra judiciary act like "The Protection of Crops and Livestock Act" or "The Protection of Crops, Livestock and the Environment Act", in which not only the grazing land is the issue, but with parallel and thorough protection of crops and croplands. Another effort must focus on the pastoralist cultural ties. Much is documented about many pastoralists regarding their mode of production to be their cultural and traditional heritage $[3,28]$ that cannot be intervened. An educational effort is needed to make the traditionalists understand the concept of farming systems, and that the systems evolve naturally and inevitably with resource and environmental challenges. They must be made to understand that just like shifting cultivation and slash and burn crop agriculture practices are out-modeled and becoming extinct, livestock rearing practices like pastoralism are in the same trend towards extinction and settled intensive use of resources.

\subsection{General Overview}

The problem of pastoralist-farmer conflict over land use has been extensively analyzed in literature. An immediate cause of the conflict has been cited to be water and land scarcity thus competition over those natural resources [38-41]. This is further intensified by climate change. As pastoralists rely on seasonal movements of their livestock to wetter parts for search of pastures and water during the dry season; when there is shortage of rainfall the movement may necessarily involve encroaching the more extensively cultivated and settled croplands, which becomes a source of conflict. Increasing number of livestock causes overgrazing leading to expansion of pastoralist's territory usually of the drier parts towards wetter croplands; likewise increasing human population pushes farmers to settle and cultivate crops in drier parts surrounding wetter croplands. Additionally, pastoralists often trespass croplands while migrating or when moving livestock to water resources (rivers, etc) to drink after feeding, which may involve contact with fields with crops thus damaging the crops. Both tendencies intensify competition for the land resource, which ends up into conflict and even violent clashes. This is the depoliticized and environmentalist explanation of the causes of the pastoralist-farmer land use rivalry/conflict $[19,42]$.

The way to solve the problem of pastoralist-farmer land resource use conflict has been generally suggested to be strengthening property rights protection (PRP) and to increase the role and penetration of the state $[43,44]$. This contention has even the blessing of the World Bank, as reported by Butler and Gates [19]. Political ecologists, on the other hand, maintain a more complex view of the conflict, pointing out an additional problem of state bias in affording the PRP [45-48]. Butler and Gates [19] argue that because of the tremendous difference there is in conception of property rights of pastoralists and sedentary agriculturists, the state is often biased in one way or another, thus naturally forming an alliance with one of the groups, and further argue that the difference in conception is that of pastoralists perceiving property to be cattle, land is no one's property open to herds; while to sedentary agriculturalists land is property, which is divided between households. This definitely complicates state decision making on land security and equitable granting of property rights to land between pastoralists and farmers. Moritz [17] therefore argues that policies on land are responsible for pastoralist-farmer conflicts and hold the view that one side of the rival groups will always have greater political power, whether traditional, instated by colonialists or policies of the current administration whether national or international. This is similar to earlier contemplation by Hagmann and Mulugeta [42] that although violence between herders and crop farmers is perpetrated in non-state, depoliticised spheres (intergroup conflicts), it is directly related to the state which 
mediates resource governance, peace making and group identity.

The problem of state bias is further propounded by several workers. Moritz [17] reiterates that one mechanism of state bias is exploitation of administrative powers typically by herders, while Benjaminsen and Boubaca [49] point to the state officials (elites and bureaucrats) exploiting the conflicts through personal gain by perpetuating instead of resolving the conflicts. The publications explain that usually by accepting bribes some administrative authorities have an assured source of financial benefit from the competing interests of farmers and pastoralists [17]. Ibid has reported incidences of pastoralists damaging crops intentionally, deduction from which is that the perpetrators no longer value existing rules or legislation because they have already corrupted the authorities or they can easily defend their actions through bribes. Lartey [50] can be quoted of information from Ghana reporting some chiefs been accused by farmers of condoning with the herdsmen by receiving gifts of cattle and permitting the herdsmen to enter their chiefdoms for purposes of grazing. This is another form of bribery at local community (non or semi-state actor) level. Benjaminsen and Boubacar [49] point out that government officials may indeed use their powers to exploit institutional ambiguity to the detriment of the poor in farmerherder land use rivalry, and argue that in order to understand the origins and catalysts of the conflict it is important to know also the interests and motives of individual actors in the process of protection and assurance of rights.

Meat has a considerably lower nutritious value than cereals, and its production consumes comparatively more natural resources than vegetarian foods, as reported by Herrmann [51]. Ibid reports further that to produce one kilogram of meat requires roughly 5 - 13 times the quantity of water to produce one kilogram of wheat, in addition to in some cases meat production accelerating the rate of deforestation then contributing to soil erosion and desertification. Furthermore, Ibid reports from reliable sources that globally it has been found that livestock account for more emission of greenhouse gases than the transport sector, with about $18 \%$ of the emissions measured in carbon dioxide equivalents, which includes $9 \%$ of anthropogenic carbon dioxide emissions, 37\% methane (which has 23 times the global warming potential of carbon dioxide), and $65 \%$ of nitrous oxide (which has 296 times the global warming potential of carbon dioxide). More information showing the disparity between livestock and crop agriculture, indicates for example (according to Lugoe [28] that in 2005 agriculture contributed about $45.6 \%$ of the National Gross Domestic Product in Tanzania, roughly about $43 \%$ from the crop subsector and $2.7 \%$ from the livestock sub-sector; yet graz- ing is already occupying about 8.5 million hectares of agricultural land outside permanent pastures land (Ibid). Even though this analysis is not trying to undermine the livestock sector which is still very important, data like these are very important and they need to be used in agricultural land use planning and administration of tenure.

Whether with state bias or not, the extent to which state machinery is established and the extent to which society is organized matter in farmer-pastoralist conflict resolution. Most naturally where it exists and land use conflicts are present, the state will enact legislation on land tenure with penal sanctions against land use abuse. To what detail the legislation may deal with the conflict resolution can be a different issue, which may also be influenced by bias. Some legislations or regulations have made further steps beyond punitive measures against livestock trespassers and stray animal herders, to allocation of grazing land and demarcation of pastoralist grazing reserves, like examples in Nigeria [52-54] and Tanzania. IRIN [20] has recommended formation of special courts and special corps offices to manage tensions between farmers and pastoralists. Various workers have proposed extension, communal organization and educational approaches [55-57] as strategies that can very much curb the rival groups conflicts. All these are measures that can claim various levels of success depending on the nature of existing interaction between farmers and pastoralists, extent to which the conflict has persisted and whether there has been previous intervention and the level of success of the previous intervention. In other words, no single approach can be guaranteed of success alone, depending on the underlying specific situation. Participatory approaches have been widely advocated, like the formation of Community Development Committees reported by Ofuoku [56] and involving rural extension workers in drafting and administering Local Development Plans or LDPs [57], formation of Local Community Farmers Associations [56] and any other non-governmental or semi-governmental organizations. This can increase the level of involvement of the resource rival groups in planning consensus, but this will again depend on the level of contact that exists between the groups. Where pure nomadism is practiced, for example, the level of contact can only be very occasional or seasonal, or where demarcated pastoralist grazing land has been allocated, the level of participation can perhaps only be at a higher, supra-community level. Coupled with educational programmes targeted towards imparting attitudinal change against unregulated and unlimited land resource use, participatory measures in whatever level practiced can have impact in conflict resolution between farmers and their rival herders. 


\section{CONCLUSION AND RECOMMENDATIONS}

This situational discussion of the crop-livestock interaction in agro-ecosystems which are suitable for both crop agriculture and grazing animal production concludes that a farming system mindset is necessary for an everlasting resolution of the farmer-herder conflict. Pastoralists and pro-pastoralism advocates need to intuit and accept the reality that farming systems are in a permanent state of change and that nomadic rearing of livestock as a system is long overdue with very little chance of been practiced to-date without land use conflict. Removal of this cultural or traditional notion is important among the migratory herdsmen, but it is also necessary that state and government policy must also aim at changing the farming systems setting through explicit land use planning and a comprehensive agricultural land use legislation that strengthens more modern and settled livestock agriculture rather than migratory practice. Definition of crop agriculture boundaries is necessary, within which if livestock agriculture is to be practiced, it must be intensive with strictest ability to confine animal movements within fences or safe corridors. In Tanzanian context there has been quite a significant trend in establishing administrative and legislative machinery to regulate the crop-livestock interplay in recent years. There is general realization of underdevelopment of the livestock sector and agriculture as a whole, but perhaps there is also need to reiterate that the root cause of underdevelopment of the livestock sector is reliance on nomadic pastoralism which is still recognized in policy as a viable farming system. With soaring human population and livestock numbers, there is inevitably a threshold where extensive systems can no longer be tolerated. This is just where we have been and we are doomed to step away from.

\section{REFERENCES}

[1] Consultative Group on International Agricultural Research (CGIAR) (2012) Agriculture and rural development day 2012 "Lessons in sustainable landscapes and livelihoods". Rio de Jeneiro, Brazil. http://www.cgiar.org

[2] Organization for Economic Cooperation and Development (OECD) (2006) Agriculture: Promoting pro-poor growth. Organization for Economic Cooperation and Development, Paris.

[3] Legal and Human Rights Center (LHRC) (2010) Tanzania human rights reports 2009. Incorporating specific part on Zanzibar. Legal and Human Rights Center, Dar es Salaam.

[4] TanzaniaInvest (2013) Tanzania agriculture sector. http://www.tanzaniainvest.com/agriculture

[5] de Janvry, A. and Sadoulet, E. (2010) Agricultural growth and poverty reduction: Additional evidence. World Bank Research Observer, 25, 1-20.

http://dx.doi.org/10.1093/wbro/lkp015

[6] Mashindano, O. (2009) Growth and poverty reduction in Tanzania: Why such mismatch? Economic and Social Research Foundation (ESRF) Policy Brief Series No. 1.

[7] Fresco, L.O. (1986) Cassava in shifting cultivation: A systems approach to agricultural technology development in Africa. Royal Tropical Institute, Amsterdam.

[8] Beets, W.C. (1990) Raising and sustaining productivity of smallholder farming systems in tropics. AgBe Publishing, Alkmaar.

[9] GERDAT (1982) Le gazette des systemes (Mission systemes agraires). Groupment d'Etudes et de recherches pour le developpement de l'agronomie tropicale [The systems gazette (agricultural systems mission)]. Group for Tropical Agricultural Development Studies and Research (GERDAT), Montpellier.

[10] Krantz, B.A. and Associates (1974) Cropping patterns for increasing and stabilizing agricultural production in the semi-arid tropics. International Workshop on Farming Systems, International Center for Research in Semi-Arid Tropics (ICRISAT), Hyderbad, 18-21 November 1974.

[11] Dixon, J., Guliver, A. and Gibbon, D. (2001) Farming systems and poverty. Improving farmer's livelihood in a changing world (summary). FAO and World Bank, Rome and Washington DC.

[12] Ruthernberg, H. (1983) Farming systems in the tropics. 3rd Edition, Clarendon Press, Oxford.

[13] NLP (2006) National livestock policy. The United Republic of Tanzania Ministry of Livestock Development. 2006.

[14] Pratt, D.J., Le Gall, F. and de Haan, C. (1997) Investing in pastoralism. Sustainable natural resource use in Arid Africa and the Middle East. World Bank, Washington DC. http://dx.doi.org/10.1596/0-8213-3943-5

[15] Collins Dictionary (2013) Ranching. 10th Edition, Collins English Dictionary - Complete and Unabridged. http://dictionary.reference.com/browse/ranching

[16] Farlex (2013) Ranch. The free dictionary by Farlex. Farlex Inc., Huntingdon Valley, Pennsylvania.

[17] Moritz, M. (2009) Farmer-herder conflicts in Sub-Saharan Africa. The encyclopaedia of Earth. http://www.eoearth.org/article/Farmer-herder conflicts i n_Sub-Saharan_Africa?topic $=49530$

[18] Smith, T.L. (1969) Agricultural-pastoral conflict: A major obstacle in the process of rural development. Journal of Inter-American Studies, 11, 16-43. http://dx.doi.org/10.2307/165400

[19] Butler, C.K. and Gates, S. (2010) Communal violence and property rights. Centre for the Study of Civil War (PRIO), Oslo.

[20] Integrated Regional Information Networks (IRIN) (2012) Bukina Faso: Preventing conflict between farmers and herders. IRIN, Kano.

[21] Integrated Regional Information Networks (IRIN) (2009) Nigeria: Farmer-pastoralist clash leaves 32 dead. IRIN, 
Kano.

[22] APA News (2012) Over 280 die in Nigeria in farmers, pastoralists conflicts in 5 years. http://www.apanews.net/photo/en/photo.php? Id =163158

[23] Aljazeera (2012). Deadly violence on Mali-Bukina Faso border. Aljazeera.

[24] Atkilt, D. (2003) Farmer herder conflict over natural resources in north east Ethiopia. M.Sc. Thesis, Addis Ababa University, Addis Ababa.

[25] Fujimoto, T. (2009) Armed herders, unarmed farmers, and the state. An analysis of violent conflicts in the middle Omo valley with reference to case of Malo, south west Ethiopia. Nilo-Ethiopian Studies, 13, 63-77.

[26] Aljazeera (2012) Dozens killed in Kenya clashes. Aljazeera.

[27] World Bank (2013) Land area (sq. km): Tanzania (20082011). The World Bank group. http://data.worldbank.org/indicator/AG.LND.TOTL.K2

[28] Lugoe, F. (2011) Alligning and harmonizing the livestock and land policies in Tanzania. ESRF Discussion Paper No. 35. Economic and Social Research Foundation, Dar es Salaam.

[29] Mkinga, M. (2012) Tanzania to seek China help on farming. The Citizen.

[30] ALP (1997) Agricultural and livestock policy 1997. Ministry of Agriculture and Cooperatives, Dar es Salaam.

[31] Daily News (2012) Land: Efforts needed to end conflicts between farmers and cattle headers. Daily News Mobile Edition. http://allafrica.com/stories/201206041179.html

[32] Ihucha, A. (2004) Two dead in Maasai, Sonjo clashes. IPP Media (including the Guardian).

[33] Arusha Times (2005) After fierce clashes, Maasai and Sonjo now agree to live in peace. Arusha Times.

[34] Arusha Times (2005) One killed as Loliondo tribal clashes erupt again. Arusha Times.

[35] Pastoralists Indigenous Non-Governmental Organizations (PINGOS) (2011) PINGOs presentation: Regional sensitization seminar on the rights of indigenous population/ communities in Central and East Africa.

http://www.achpr.org/files/news/2011/08/d33/pingos pres entation.doc

[36] Balaigwa, A. (2013) Dumila violence kills one, injures ten more. The Guardian.

[37] Livestock Sector Development Programme (LSDP) (2011) Livestock sector development programme. Ministry of Livestock and Fisheries, Dar es salaam.

[38] Homer-Dixon, T.F. (1994) Environmental scarcities and violent conflict: Evidence from cases. International Security, 19, 5-40. http://dx.doi.org/10.2307/2539147

[39] Homer-Dixon, T. (1999) Environment, scarcity and violence. Princeton University Press, Princeton.

[40] Baechler, G. (1999) Violence through environmental discrimination. Kluwer Academic, Dordrecht. http://dx.doi.org/10.1007/978-94-015-9175-1

[41] Kahl, C. (2006) States, scarcity, and civil strife in the developing world. Princeton University Press, Princeton.

[42] Hagmann, T. and Mulugeta, A. (2008) Pastoral conflicts and state-building in the Ethiopian lowlands. Afrika Spectrum, 43, 19-37.

[43] North, D.C. (1990) Institutions, institutional change and economic performance. Cambridge University Press, Cambridge. http://dx.doi.org/10.1017/CBO9780511808678

[44] Knack, S. (2003) Groups, growth and trust: Cross-country evidence on the Olson and Putnam hypotheses. Public Choice, 117, 341-355. http://dx.doi.org/10.1023/B:PUCH.0000003736.82456.04

[45] Johnson, D. and Anderson, D.M. (1988) The ecology of survival. Case studies from Northeast African history. Westview Press, Boulder.

[46] Anderson, D.M. (2002). Eroding the commons: The politics of ecology in Baringo, Kenya, 1890s-1963. Ohio University Press, Athens.

[47] Turner, M.D. (2004) Political ecology and the moral dimensions of resource conflicts: The case of farmer-herder conflicts in the Sahel. Political Geography, 23, 863-889. http://dx.doi.org/10.1016/j.polgeo.2004.05.009

[48] Benjaminsen, T.A., Maganga, F.P. and Moshi Abdallah, J. (2009) The Kilosa killings: Political ecology of a farmer-herder conflict in Tanzania. Development and Change, 40, 423-455. http://dx.doi.org/10.1111/j.1467-7660.2009.01558.x

[49] Benjaminsen, T. and Boubacar, B.A. (2008) Farmer herder conflicts, pastoral marginalization and corruption: A case study from the inland Niger Delta of Mali. The Geograppical Journal, 175, 71-81. http://dx.doi.org/10.1111/j.1475-4959.2008.00312.x

[50] Lartey, L. (2010) Pastoral herdsmen and sedentary farmers-An age old conflict that defies solution. Eldis Communities, a Learning Network for Development Professionals.

[51] Herrmann, M. (2009) Food security and agricultural development in times of high commodity prices. United Nations Conference on Trade and Development (UNCTAD) Discussion Papers No. 196. United Nations, Geneva.

[52] Musa, I. (2009) Nigeria: FG to develop 415 grazing reserves-Ruma. Daily Trust.

[53] Waters-Bayer, A. and Taylor-Powell, E. (1986) Population and land use in the sub-humid zone of Nigeria. In: von Kaufmann, R., et al., Eds., Livestock Systems Research in Nigeria's Subhumid Zone, Proceedings of the 2nd ILCA/NAPRI Symposium, Kaduna, 29 October-2 November 1984, International Livestock Centre for Africa (ILCA), Addis Ababa, 37-58.

[54] International Livestock Centre for Africa (ILCA) (1979) Grazing reserves and development blocks: A case study from Nigeria development requirements. Chapter 8: Land-use and development strategies. ILCA systems study 2: Livestock production in the sub-humid zone of West Africa, A regional review. FAO Corporate Document Repository.

[55] Nweze, N.J. (2005) Minimizing farmer-herder conflicts 
in Fadama areas through local development plans. Implications for increased crop/livestock productivity in Nigeria. The 30th Annual Conference of the Nigerian Society for Animal Production, University of Nigeria, Nsukka, 20-24 March 2005.

[56] Ofuoku, A.U. (2009) Role of community development committees in farmer-herder conflicts in central agricultural zone of Delta State, Nigeria. Journal of Alternative Perspectives in the Social Sciences, 1, 921-937.

[57] Ofuoku, A.U. and Isife, B.I. (2009) Causes, effects and resolution of farmer-nomadic cattle herders conflict in Delta State, Nigeria. International Journal of Sociology and Anthropology, 1, 47-54. 